\title{
RELATIONSHIP BETWEEN FINANCIAL CRISIS AND FOREIGN DIRECT INVESTMENT IN DEVELOPING COUNTRIES USING SEMIPARAMETRIC REGRESSION APPROACH
}

\author{
Meltem Ucal ${ }^{1}$, Kıvılcım Metin Özcan ${ }^{2}$, \\ Mehmet Huseyin Bilgin ${ }^{3}$, Julius Mungo ${ }^{4}$ \\ 1, ${ }^{3}$ Kadir Has University, Kadir Has Cad., 34083 Istanbul, Turkey \\ E-mail:1'msengun@khas.edu.tr; ${ }^{3}$ mhbilgin@khas.edu.tr \\ ${ }^{2}$ Bilkent University, 06800 Ankara, Turkey \\ E-mail:kivilcim@bilkent.edu.tr \\ ${ }^{4}$ Humboldt-Universit"at zu Berlin, 10178 Berlin, Germany \\ E-mail:mungo@cms.hu-berlin.de \\ Received 18 January 2009; accepted 20 January 2010
}

\begin{abstract}
This paper analyzes whether and to what extent the inflow of FDI is affected before and after the occurence of a financial crisis in developing countries. The paper uses a semiparametric Generalized Partial Linear Models (GPLM) regression approach to check the appropriateness and effectiveness of financial crisis in the FDI regression model. The results indicate that FDI inflows decrease in the years after a financial crisis and an upturn in FDI inflows the year before a financial crisis hit the country.

Keywords: Semiparametric regression approach, Generalized Partial Linear Models (GPLM), financial crisis, foreign direct investment, developing countries.

Reference to this paper should be made as follows: Ucal, M.; Özcan, K. M.; Bilgin, M. H.; Mungo, J. 2010. Relationship between financial crisis and foreign direct investment in developing countries using semiparametric regression approach, Journal of Business Economics and Management 11(1): 20-33.
\end{abstract}

\section{Introduction}

Foreign direct investment (FDI) is important to many developing economies for various reasons. Both economic theory and empirical evidence indicate that FDI has a beneficial influence on developing host countries. In fact, FDI has played an important role in the economic development of many countries. For instance, Urata (1999) claimed that FDI contributed significantly to the rapid economic growth of East Asia from the mid-1980s. Fan and Dickie (2000) argued that FDI has made an important contribution to the economic development of the ASEAN-5 (Indonesia, Malaysia, Philippines, Singapore and Thailand) economies. Therefore, many developing economies, such as the Asian economies, have liberalized FDI policies to reap the benefits from FDI. In

\footnotetext{
${ }^{1}$ Corresponding Author.
} 
addition to contributing to the economic growth, as mentioned by Herman et al. (2004), FDI inflows provide economic benefits such as increased competition, technological spillovers and innovations, and increased employment.

However, some empirical literature reveals contrary findings for an exogenous positive effect of FDI on economic growth due to the institutional limitations of a country's capacity to take advantage of FDI externalities such as a lack of financial markets. Borensztein et al. (1998) showed that FDI is an important vehicle for the transfer of technology, contributing relatively more to growth than domestic investment. However, the higher productivity of FDI holds only when the host country has a minimum threshold stock of human capital. Thus, FDI contributes to economic growth only when a sufficient absorptive capability of the advanced technologies is available in the host economy. In fact, Alfaro et al. (2004) provide further evidence that only countries with welldeveloped financial markets gain significantly from FDI in terms of their growth rates.

Many factors other than growth affect FDI inflows. The literature has indicated that FDI inflows are determined by market size, degree of openness, the role of institutional factors and degree of integration of the world economy. At the same time, other factors such as labor and energy costs, domestic tax rates, level of investment incentives, and legal and institutional environments are significantly associated with FDI inflows in a single country analysis. Among them Tvaronavičienè and Grybaite (2007) estimate impact of foreign direct investment on growth of economy in Lithuania and test if different levels of penetration of foreign capital into certain economic activities serve as important factor affecting their economic growth. Kosekahyaoglu (2006) examines the structure of FDI flows into Turkey and the Central and Eastern European Countries (CEECs) as well as the other new members of the European Union (EU). Kosekahyaoglu's paper introduces key economic and political factors that have an impact on FDI such as, the macroeconomic performance, the production cost and the size of domestic market. In addition the relationship between FDI and trade flows for Turkey, the Czech Republic, Hungary and Poland is investigated by using the Granger causality methodology.

The regional distribution of FDI can be considered as an indicator of economic openness and integration in the world market. In fact, Pazienza and Vecchione (2009) showed that Italy has a strong potential for attracting investment, but the inward flow of FDI is very small with respect to what happens in other countries. Institutional factors such as political and economic stability, transparency regulations and corruption are recently gained importance in explaining the behavior of the foreign direct investment inflows in developing countries. Hyun (2006) analyzes the short-run and long-run dynamics between quality of institutions and foreign direct investment (FDI) in the panel of 62 developing countries covering the period 1984-2003. Institutional quality and FDI are found to have bi-directional cointegrating relationship in the long-run. However, there is no evidence in favor of short-run causality between two variables. Dumludag (2009) uses data obtained from a questionnaire which applied to the executives of 52 multinational corporations operating in Turkey in 2006 and examines the role of several institutional factors explaining the behavior of the foreign direct investment inflows in Turkey. As stated by Fan and Dickie (2000), a large number of studies have examined FDI; 
however, few have gone beyond qualitative assertions regarding FDI and financial crisis. Furthermore, the results of these studies have been mixed. It can be said that financial crises affect the aggregate economy in various dimensions. These crises cause great damage to world economies. UNCTAD represents a contrasting optimistic view. One can summarize that FDI may greatly contribute to the eventual recovery of crisishit countries after the Asian crisis (Fukao 1999). In this context, Nunnenkamp (2006) stated, "Since recent financial crises in Asia and Latin America, developing countries have been strongly advised to rely primarily on FDI in order to promote economic development on a sustainable basis" (para. 1).

The financial crisis had a discouraging impact on FDI because of increasing uncertainty in macro-economic performance that resulted from the crisis and its aftermath (Urata 1999). In fact, the real world data indicate that the negative effect of the financial crisis on the FDI inflows is strong. Despite the fact that global FDI inflows rose by $30 \%$ to $\$ 1,833$ billion in 2007, FDI decreased during the crisis because of the climate of increased uncertainty. In other words, the global financial crisis had a limited impact on FDI flows in 2007 but began to bite in 2008 (UNCTAD 2008a). Based on available FDI data, UNCTAD estimated that the global FDI flows for the whole of 2008 were expected to be about \$1,600 billion, representing a 10\% decline from 2007 .

Indeed, the financial crisis and economic downturn affected firms' plans for future foreign investment. A UN survey (UNCTAD 2008b) on global investment prospects showed that the current financial crisis and economic downturn are making corporations more cautious about future foreign investment. According to the survey's results, only $21 \%$ of companies anticipate a large increase in their FDI expenditures over the next three years, compared to $32 \%$ the previous year. Obviously, the global financial crisis has already had a significantly negative impact on FDI plans for the next three years. As a result of the slowdown in the world economy and the liquidity crisis, FDI has slowed down in many countries, such as China and South Korea. The latest figures suggested a slowdown in the FDI growth rate, which was $45.6 \%$ for the first half of 2008 (China Daily 2008). Furthermore, FDI into Korea fell for the first time in six quarters since the second quarter of 2007 (Hyo-sik 2008). The situation indicated that the impact of the global financial crisis on FDI has started to become clearer. On the other hand, mergers and acquisitions (M\&A) activity has begun to slow down markedly. Additionally, corporate profits and syndicated bank loans are also declining. Moreover, both inflows to and outflows from developed-country economies may decline due to the financial crisis (UNCTAD 2008a).

As mentioned above, limited studies have been conducted on the effects of financial crisis on FDI. Most of these studies have been related to FDI inflows into Asian countries during the Asian financial crisis in 1997/98. For instance, Athukorala (2003) examined FDI in the Asian crisis, Thu (1998) investigated the effects of the Asian financial crisis on FDI in Vietnam, Kian Wie (2006) analyzed the Indonesian investment climate and FDI after the Asian financial crisis, and Edgington and Hayter (2001) examined the extent to which the Asian financial crisis impacted the behavior of Japanese FDI in the manufacturing sector. Further-more, Urata (1999) analyzed the impact of the crisis on Japanese FDI. 
Some other studies investigated the relationship between FDI and financial crisis for Asian countries. It should be mentioned that FDI has played an important role in the economic development of Asian countries since the 1980s (Fukao 1999). Moreover, Fan and Dickie (2000) assessed the contribution of FDI to the growth and stability of ASEAN-5 economies by comparing the inflows before and during the Asian financial crisis. In addition, Graham and Wada (2000) analyzed the relationship between financial crisis and FDI for Mexico. Ezirim and Muoghalu (2006) investigated the relationship between foreign investment burden and external debt crisis in Nigeria. Hutchison and Noy (2005) examined the output effects of banking and currency crises in emerging markets.

The literature includes also many studies which examine how to detect financial crisis, bank and currency crises. These studies have used combination of macro-economic indicators and early warning signals to predict financial crises and speculative pressure indices for currency crises (Coulibaly 2009; Ozlale and Metin-Ozcan 2007; Kaminsky and Reinhart 1998; Eichengreen et al. 1996). Apoteker and Barthelemy (2005) indicated three types of country crises: cyclical crises, exchange rate crises, and default crises. Cyclical crises are calculated as negative real GDP growth rate associated with a very shape decrease (more than 7\%) of this growth rate from the previous year. Exchange rate crises are calculated as high depreciation rate of the real exchange rate against USD. Default crises are calculated using documents from the Institute for International Finance (IIF). Having motivated from above given literature on FDI and financial crisis relationship, the purpose of this paper is to analyze whether and to what extent the inflow of FDI is affected before and after the occurrence of a financial crisis in developing countries. This paper mainly contributes to the literature by applying a semiparametric Generalized Partial Linear Model (GPLM), where a financial crisis is treated as (dummy) binary variables to be estimated. To our knowledge, such an approach has not been employed to study the relationship between financial crisis and $\mathrm{FDI}^{2}$. In this case, our analysis using the semiparametric GPLM emerges as a pioneering study for developing economies.

The paper is organized as follows: Section 2 presents the literature review of previous studies. Section 3 defines data, methods, and evidence. Section 4 concludes and suggests the relationship between FDI and financial crises.

\section{Literature Review: FDI and Financial Crisis}

As noted in the introduction, most studies on the relationship between financial crisis and FDI are related to the Asian financial crisis. A large number of these papers investigated FDI inflows to Asian countries before and after the crisis of 1997-98. The Asian financial crisis, which broke out in Thailand in March 1997, caused great damage to Asian economies. However, the Asian financial crisis affected the economies of various countries differently.

\footnotetext{
${ }^{2}$ Girma and Wakelin (2001) examined the regional impact of foreign-owned establishments on the performance of domestic establishments in the electronics industry in the UK by using semiparametric analysis but not semiparametric GPLM.
} 
Thu (1998) analyzed the effects of the Asian financial crisis on foreign investment in Vietnam. The author reported that $71.53 \%$ of foreign investment in Vietnam came from Asia-Pacific countries, so Vietnam could not escape the effects of the Asian financial crisis. The realization of many licensed projects was delayed and the amount of licenses granted in 1997-98 was reduced compared with 1996 because of the financial crisis. As a result, as stated by Thu, foreign investment in Vietnam decreased during those two years. Furthermore, many foreign-invested companies had to downsize because their markets narrowed.

Athukorala (2003) also examined FDI during the financial crisis in East Asia. The author analyzed FDI policy and the overall investment climate in the five crisis-hit countries (Thailand, Malaysia, Indonesia, Korea, and the Philippines). The findings suggested that FDI was a relatively stable source of foreign capital in the crisis. Additionally, Athukorala examined the behavior of FDI compared to other forms of capital flows after the onset of the crisis. Nevertheless, "contrary to some pessimistic predictions, the Asian financial crisis has not resulted in a major discontinuity in FDI inflows to the region, apart from a modest decline in the immediate aftermath of the crisis" (Athukorala 2003).

Nevertheless, Thu (1998) claimed that the Asian financial crisis had some favorable effects on Vietnam. For instance, the crisis forced the government to take measures to prevent the financial crisis, reform economic management, and improve the investment environment (Thu 1998). In this respect, structural reforms are very important for developing economies to attract more FDI inflows. In fact, "structural reforms are more than just a signal. They generate real benefits to foreign investors by affecting the key parameters upon which the decision to invest in a foreign country is taken" (Campos and Kinoshita 2008). Furthermore, Kian Wie (2006) analyzed the Indonesian investment climate and FDI after the Asian financial crisis. The author reported that after the crisis, domestic investment and FDI dramatically declined, largely as a result of the deteriorating investment climate. Kian Wie mentioned that since the $1980 \mathrm{~s}$, the Indonesian government has attempted to improve the investment climate for both domestic and foreign investors. As a result of the improvement in the investment climate, FDI inflows have risen rapidly since the late 1980s. Most of the export-oriented FDI came from the East Asian countries. In this period, "many Korean and Taiwanese were relocating their labor-intensive operations to lower-wage countries in Southeast Asia, including Indonesia" (Kian Wie 2006). Despite these findings, Indonesia experienced net FDI outflows from 1998 to 2003 because of the Asian financial crisis. As a result of a notable decrease in the competitiveness of Indonesia as a suitable location for FDI, Kian Wie argued that many Korean and Japanese firms left Indonesia to relocate to countries with a more favorable investment climate. However, in 2004 and the first half of 2005, net FDI inflows were again recorded.

Loungani and Razin (2001) investigated the question of how beneficial FDI is for developing countries. The authors stated that FDI has proven to be resilient during financial crises and claimed that FDI in East Asian countries was remarkably stable during the Asian financial crisis. Furthermore, they mentioned that the resilience of FDI during the financial crises was also evident during the Mexican crisis of 1994-95 and the Latin 
American debt crisis of the 1980s. The authors argued that the resilience of FDI during financial crises may lead many developing countries to regard it as the private capital inflows of choice.

On the other hand, some researchers have argued that FDI is more stable than other forms of international financial flows during times of financial crisis. Graham and Wada (2000) analyzed the crisis of 1995 and the response of FDI and foreign-controlled enterprises in Mexico. The authors reported that it was clear that FDI from the United States was indeed stable. However, as the authors mentioned, during the crisis year, Mexico experienced a slowdown of FDI influx, but there was no exit for this form of investment.

Some other studies have investigated the behavior of Japanese FDI during the Asian financial crisis. The financial crisis changed the FDI environment drastically; that is, the crisis had a discouraging impact on FDI. For instance, Urata (1999) analyzed the impact of financial crisis on Japanese FDI and found that Japanese FDI in the latter half of 1997 declined in many Asian economies. Nevertheless, Edgington and Hayter (2001) examined the extent to which the Asian financial crisis impacted the behavior of Japanese FDI in the manufacturing sector. In general, their findings suggested that Japanese TNCs have not fled Asia but rather responded in the following manner: Although it was set to decline thereafter, at least for the short term, flows of Japanese FDI into Asia overall held steady during the Asian financial crisis.

Some other studies analyzed the relationship between economic crisis and FDI inflows using various economic aspects. For instance, Ezirim and Muoghalu (2006) investigated how and to what extent investment burden was affected by exchange rate conditions and external debt crisis in Nigeria. Their study specified four foreign investment models to determine relationships between foreign investment income remittances and such predictors as exchange rates, external debt burden, and oil prices in international markets. The authors found clear-cut and significant relationships between the three external sector economic crises.

Hui and Shang-Jin (2009) examine that whether capital flows affect the degree of credit crunch faced by a country's manufacturing firms during the 2007-09 crises. Examining 3823 firms in 24 emerging countries, they find that the decline in stock prices was more severe for firms that are intrinsically more dependent on external finance for working capital. The volume of capital flows has no significant effect on the severity of the credit crunch. However, the composition of capital flows matters: pre-crisis exposure to non-FDI capital inflows worsens the credit crunch, while exposure to FDI alleviates the liquidity constraint. Doraisami (2007) argues that FDI flows in Malaysia contributed to vulnerability to crisis by causing chronic current account deficits and was associated with a slowdown in export growth prior to the crisis. This suggests that when assessing a country's vulnerability to financial crisis, emphasis should not only be placed on the reversibility of flows but also on the macroeconomic impact of these flows.

Thangavelu et al. (2009) studies the trends in foreign direct investment (FDI) flows into selected South-East Asian and East Asian economies after the Asian crisis. Empirical evidence indicates that South-East and East Asian economies are recovering from the Asian crisis with strong output growth driven largely by export growth. They also 
suggest that there might have been structural changes in the regional economies that could have led to a downward shift in the output growth of Asian economies in the post-crisis period. This raises the issue of the sustainability of their output growth in the post-crisis period.

\section{Data, Method, and Evidence}

For a long time, parametric and nonparametric regressions were main methodologies while recently, semiparametric regressions gained more importance. This is mainly because semiparametric regression cut downs on the high risk of misspecification relative to a fully parametric model and avoids some serious disadvantages of fully nonparametric methods. Firstly, the partial linear model was introduced by Engle et al. $(1986)^{3}$ in the semiparametric regression models. Afterwards, most work is focused on the semiparametric regression models. Most especially, the generalized partial linear model has become quite popular in the recent years (e.g. Müller 2000; Cantoni and Ronchetti 2001; Härdle et al. 2004; Bertschek and Müller 2006) owing to the flexibility, determining to the variety of the statistical problems and easy visualization-interpretation of the results

\subsection{Data}

Data are available for 148 countries for the period 1995 and $2007^{4}$. Data are from the World Bank's World Development indicators (WDI) (2008) and UNCTAD (2008c) (major FDI indicators: WIR). FDI is a measurement of the FDI inflows to the host country in FDI inflow per year. Crisis is a dummy variable that takes the value 1 in the years after a financial crisis and zero otherwise on an observation basis. The Crisisc is also a dummy variable that takes the value 1 a year before a financial crisis and zero otherwise.

\subsection{Method}

Classification techniques are used in numerous statistical applications. The main target of any classification model is to classify variable of the interest in two or more groups based on a predicted result associated with each group. Various parametric and nonparametric methods can be applied to analyze classification of variables of interests. For example linear regression and logistic regression are the standard parametric techniques. The advantage of these techniques are several namely, easy estimation and easy interpretation. The nonparametric methods, unlike the parametric methods, make no assumption about the distribution. Therefore one can easily used nonparametric methods when the data does not fulfill statistical assumptions. Finally, the semiparametric methods are between parametric and nonparametric methods by making assumptions that are of intermediate strength between the parametric and nonparametric approaches. Therefore the semiparametric models reduce the risk of misspecification relative to a parametric model. Let $\mathrm{Y}$ be a random variable taking the values 0 or 1 . The problem on hand to estimate the probabil-

\footnotetext{
${ }^{3}$ The paper analyzes the effect of weather on electricity demand in which authors assumed the relationship between temperature and electricity usage was unknown while other related factors such as income and price were parameterized linearly.

${ }^{4} 148$ countries were selected as developing countries defined by UNCTAD.
} 
ity of the event $\{Y=1\}$ given a vector of explanatory variables $X$. The logistic regression is a particular case of the so-called generalized linear model. It is basically generalization of Speckman's estimator proposed by Speckman (1988). Here, we are interested in statistical models classifying the crisis in two groups: before crisis and after crisis. We analyzed the relationship between financial crisis and inflow of FDI for developing countries. The econometric approach is a generalized partial linear regression analysis that takes into account that FDI may differ depending on whether or not crisis occurs.

The method for the regression analysis is based on generalized partial linear model (GPLM) (see McCullagh and Nelder 1989) in the form

$$
E(Y \mid X, T)=G\left\{X^{T} \beta+m(T)\right\} .
$$

$E(Y \mid X, T)$ represents expected value of the dependent variable $Y$ given $X, T$, which are vectors of explanatory variables. $X^{T} \beta+m(T)$ is linked to the dependent variable $Y$ through a known link function $G($.$) . The parameter vector \beta$ and the nonparametric estimate for $m($.$) need to be estimated. We estimate the GPLM for the data, based on$ the idea that an estimate $\hat{\beta}$ can be found for known $m($.$) and an estimate \hat{m}($.$) can$ be found for known $\beta$. We follow the profile likelihood method based on the fact that the conditional distribution of $Y$ given $X$ and $T$ is parametric. The essential method for estimation is to fix the parameter $\beta$ and to estimate the least favorable nonparametric function independent of this fixed $\beta$. The resulting estimate for $m_{\beta}(\bullet)$ is then used to construct the profile likelihood for $\beta$.

Profile Likelihood Algorithm

- updating step for $\beta$

$$
\beta^{\text {new }}=\left(\tilde{X}^{T} W \tilde{X}\right)^{-1} \tilde{X}^{T} W \tilde{Z}
$$

with

$$
\tilde{X}=\left(1-S^{P}\right) X
$$

$$
\tilde{Z}=\tilde{X} \beta-W^{-1} v \text {, }
$$

where $S^{P}$ defines the smooth matrix with elements

$$
S_{i j}^{P}=\frac{l_{i}^{\prime \prime}\left(X_{i}^{T} \beta+m_{j}\right) K_{H}\left(T_{i}-T_{j}\right)}{\sum_{i=1}^{n} l_{i}^{\prime \prime}\left(X_{i}^{T} \beta+m_{j}\right) K_{H}\left(T_{i}-T_{j}\right)} .
$$

$\mathrm{W}$ is the diagonal matrix that contains the first $l_{i}^{\prime}$ and second $l_{i}^{\prime \prime}$ derivatives of $l_{i}\left(X_{i}^{T} \beta+m_{j}\right)$ respectively. $\tilde{Z}$ is an adjusted dependent variable.

- updating step for $m_{j}$

$$
m_{j}^{\text {new }}=m_{j}-\frac{\sum_{i=1}^{n} l_{i}^{\prime}\left(X_{i}^{T} \beta+m_{j}\right) K_{H}\left(T_{i}-T_{j}\right)}{\sum_{i=1}^{n} l_{i}^{\prime \prime}\left(X_{i}^{T} \beta+m_{j}\right) K_{H}\left(T_{i}-T_{j}\right)} .
$$


From $\beta^{\text {new }}$, the parametric part of the model is updated with a nonparametrically modified design matrix $X$, hence a semiparametric method. For details on this estimation procedure, see Robinson (1988), Schimek (2000), Eubank et al. (1998), Severini and Staniswalis (1994), Härdle et al. (1998), Müller (2001).

\subsection{Relating FDI Inflows on Crisis and Crisisc: Semiparametric Evidence for Developing Countries}

The descriptive statistics for our data application are given in Table 1. In the empirical implementation of our model, the variables involved are FDI and two dummy-variables, Crisis and Crisisc. Figure 1 illustrates the relationship between FDI on both variables, Crisis and Crisisc. Because these variables are binary, relative frequencies are obtained by grouping the FDI variable into equi-spaced intervals. Beyond approximately 2.4 of FDI, observations are relatively space.

We applied the GPLM model to obtain estimates of $\beta$ and the nonparametric function $m$. For our model fit, we used the binomial distribution and the Gaussian link function (Probit). Table 2 presents parameter estimates $b$ for both regressions (FDI versus Crisis and FDI versus Crisisc). The testable hypothesis of this paper is that a financial crisis influences FDI inflows. Financial crisis can have both positive and negative effects on the inflow of FDI for the developing countries depending on the use of dummy variables. The estimated coefficient of Crisis is negative and significant, and the coefficient for Crisisc is positive and significant. The GPLM model fit (see Figure 2) shows partially linear functions for the FDI and crisis relationship. The structures in these figures confirm our estimated results in that the influence of crisis on FDI is more negative, whereas the effect of Crisisc on FDI is positive. Moreover, results for different profiles of the estimated $m$ (.) functions for different bandwidths (h) gives some indication of possible deviance of $m$ (.) from linear functions.

Table 1. Descriptive statistic

\begin{tabular}{cccccc}
\hline Variables & Minimum & Maximum & Mean & Median & Std. Error \\
\hline FDI & -1499.9 & 83521 & 3376.5 & 338.91 & 9872.3 \\
\hline Crisis & 0 & 1 & 0.50 & 0 & 0.502 \\
\hline Crisisc & 0 & 1 & 0.51 & 1 & 0.501 \\
\hline
\end{tabular}
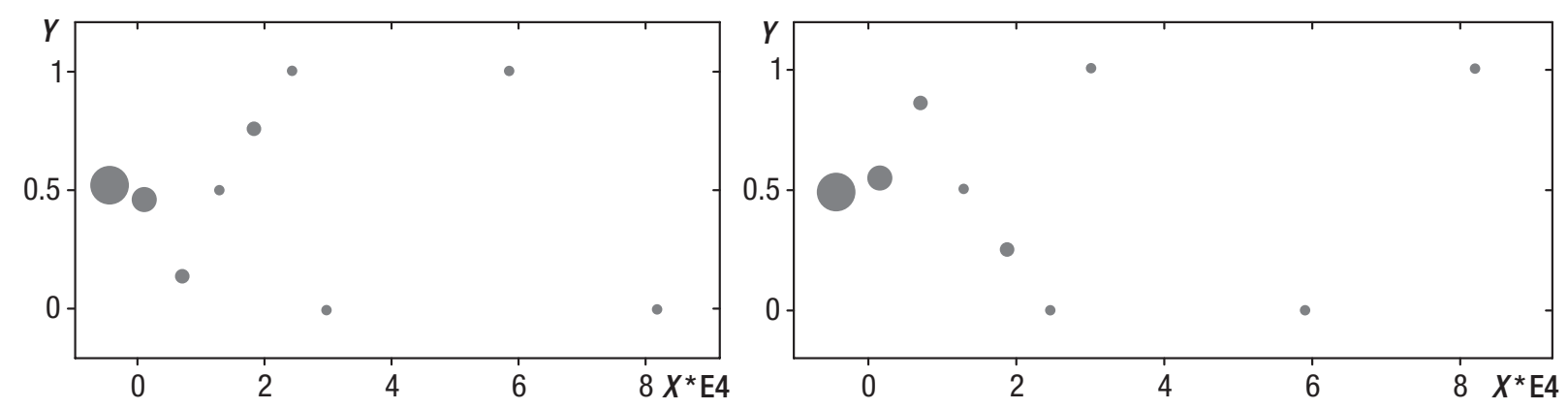

Fig. 1. FDI (grouped into equi-spaced intervals) versus the relative frequencies of Crisis (left) and Crisisc (right) 
Table 2. The generalized partial linear regression model estimates

\begin{tabular}{ccc}
\hline Coefficients & Crisis (t-values) & Crisisc (t-values) \\
\hline Constant & - & - \\
\hline $\boldsymbol{\beta}$ & $-4.93 \mathrm{e}-05(-0.49)$ & $4.55 \mathrm{e}-05(0.45)$ \\
\hline Log-likelihood & -97.71 & -96.79 \\
\hline $\mathbf{R}^{\mathbf{2}}$ & 0.057 & 0.056 \\
\hline AIC & 207.38 & 207.56 \\
\hline BIC & 228.31 & 228.48
\end{tabular}
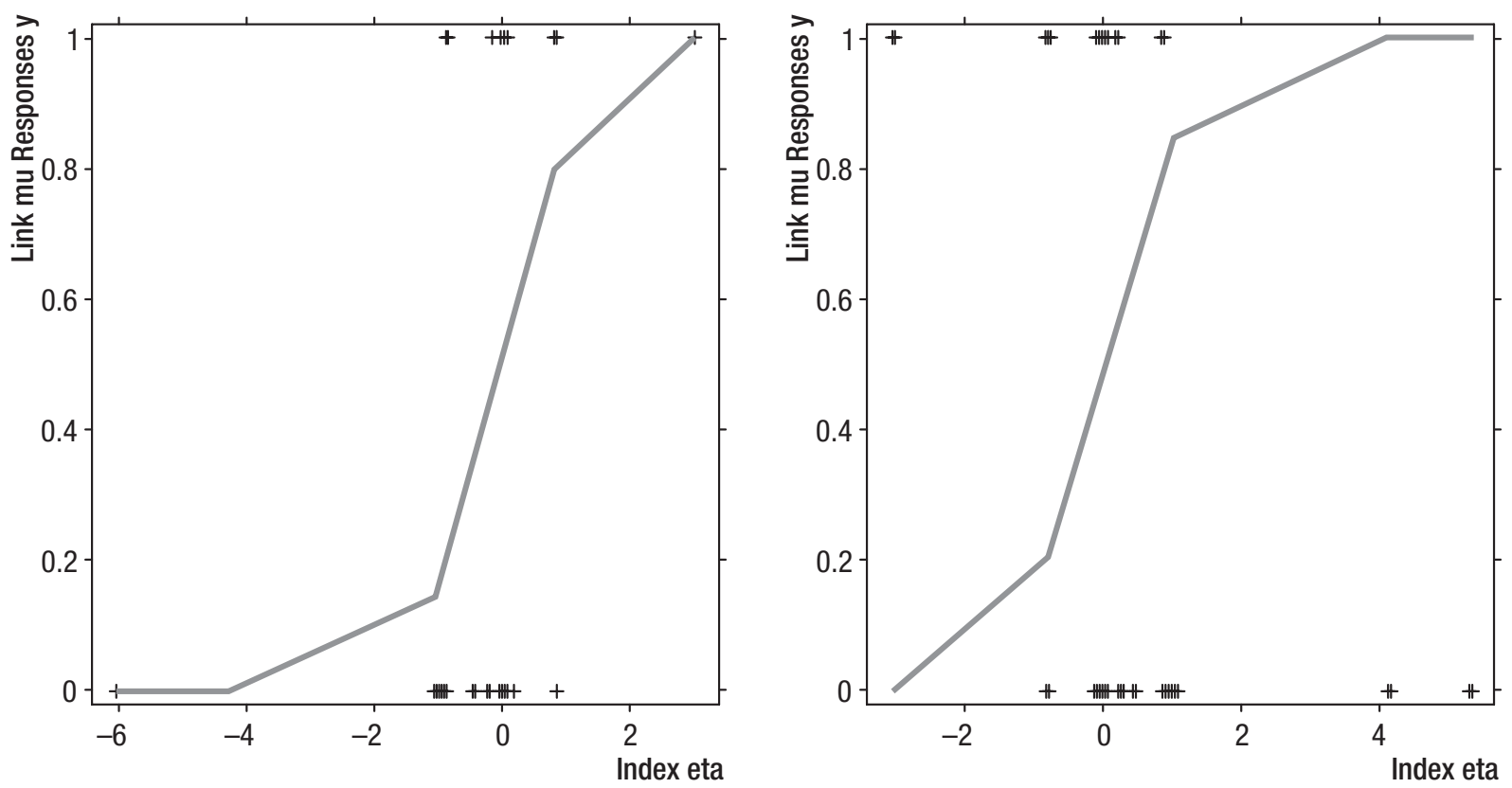

Fig. 2. General partial linear model fit: (left) FDI versus crisis; (right) FDI versus Crisisc. Fit uses the binomial distribution and the Gaussian link function, $h=0.09$

\section{Conclusion}

In this paper we empirically analyze whether financial crisis influences FDI inflows using panel data of 148 developing countries for the period 1995 and 2007 from the World Bank's World Development indicators (WDI) (2008) and UNCTAD (major FDI indicators: WIR, 2008c). Fitting a semiparametric Generalized Partial Linear Model (GPLM) our results showed that financial crisis (Crisis) exerts a downturn effect and Crisisc has an upturn effect on FDI inflows. The results are supported by the World Association of Investment Promotion Agencies, which anticipates a 15\% decline in FDI in 2009 because of the last financial crises. In fact, in 2008, FDI to Turkey and India decreased $40 \%$ and decreased $20 \%$ in China. Additionally, the UNCTAD 2008 report indicated that FDI inflows and outflows may decelerate in developing countries. The firms' willingness to increase their capacity and to invest abroad will be restricted by 
the financial crisis especially in developing countries. Consequently, FDI will return to ordinary processes when the financial crisis ends. To our knowledge the FDI and financial crisis relationship is not analyzed by using semiparametric GPLM. Future work will be directed at a tighter parameterization and use more sample information in estimation in order to identify the influences of crisis on FDI.

\section{References}

Alfaro, L.; Chanda, A.; Kalemli-Ozcan, S.; Sayek, S. 2004. FDI and economic growth, the role of local financial markets, Journal of International Economics 64(1): 89-112. doi:10.1016/S0022-1996(03)00081-3

Apoteker, T.; Barthelemy, S. 2005. Predicting financial crises in emerging markets using a composite non-parametric model, Emerging Markets Review 6(4): 363-375.

doi:10.1016/j.ememar.2005.09.002

Athukorala, P. C. 2003. Foreign direct investment in crisis and recovery: Lessons from the 19971998 Asian crises, Australian Economic History Review 43(2): 197-213.

doi:10.1111/1467-8446.t01-1-00051

Bertschek, I.; Müller, M. 2006. Productivity effects of IT-Outsourcing: Semiparametric evidence for German companies, in S. Sperlich, W. Härdle, G. Aydinli, The Art of Semiparametrics, Heidelberg, 130-154.

Borensztein, E.; De Gregorio, J. ; Lee, J.-W. 1998. How does foreign direct investment affect economic growth? Journal of International Economics 45(1): 115-135.

doi:10.1016/S0022-1996(97)00033-0

Campos, N. F.; Kinoshita, Y. 2008. Foreign direct investment and domestic financial reform: A marriage made in heaven? [online] [15 January 2009]. Available from Internet: <http://www.imf. org/external/np/vc/2008/032408.htm>

Cantoni, E.; Ronchetti, E. 2001. Robust inference for generalized linear models, Journal of the American Statistical Association 96(455): 1022-1030. doi:10.1198/016214501753209004

China Daily 2008, October 11. FDI slows down in China amid global financial crisis [online] [10 February 2009]. Available from Internet: <http://www.china.org.cn/business/ 2008-10/11/ content_16597549.htm>.

Coulibaly, B. 2009. Currency unions and currency crises: An empirical assessment, International Journal of Finance and Economics 14(3): 199-221. doi:10.1002/ijfe.363

Dumludag, D. 2009. An analysis of the determinants of foreign direct investment in Turkey: The role of the institutional context, Journal of Business Economics and Management 10(1): 15-30. doi:10.3846/1611-1699.2009.10.15-30

Doraisami, A. G. 2007. Financial crisis in Malaysia: Did FDI flows contribute to vulnerability? Journal of International Development 19(7): 949-962. doi:10.1002/jid.1358

Edgington, D. W.; Hayter, R. 2001. Japanese direct foreign investment and the Asian financial crisis, Geoforum 32(1): 103-120. doi:10.1016/S0016-7185(00)00040-3

Eichengreen, B.; Rose, A.K.; Wyplosz, C. 1996. Exchange market mayhem: The antecedents and aftermath of speculative attacks, Economic Policy 21: 249-312.

Engle, R. F.; Granger, C. W. J.; Rice, J.; Weiss, A. 1986. Semiparametric Estimates of the Relation Between Weather and Electricity Sales, Journal of the American Statistical Association 81(394): 310-320. doi:10.2307/2289218

Eubank, R. L.; Kambour, E. L.; Kim, J. T.; Klipple, K.; Reese, C. S.; Schimek, M. G. 1998. Estimation in partially linear models, Computational Statistics \& Data Analysis 29(1): 27-34. doi:10.1016/S0167-9473(98)00054-1 
Ezirim, C. B.; Muoghalu, M. I. 2006. Exchange rate determination, foreign investment burden and external debt crisis in less-developed countries: Nigerian experience, International Journal of Business and Economics Perspectives 1(1): 1-15.

Fan, X.; Dickie, P. M. 2000. The contribution of foreign direct investment to growth and stability, ASEAN Economic Bulletin 17(3): 312. doi:10.1355/AE17-3F

Fukao, K. 1999. Japanese firms take long-term view on Asian investments during crisis, The Nikkei Weekly, October 4 [online] [11 April 2007]. Available from Internet: <http://www.ier.hit-u. ac.jp/ fukao/japanese/ publication/other/2002/1999-x1.pdf>.

Girma, S.; Wakelin, K. 2001. Regional underdevelopment: Is FDI the solution? A Semiparametric analysis, CEPR Discussion Paper [online] No. 2995 [05 May 2007]. Available from Internet: $<$ http://www.cepr.org/pubs/dps/DP2995.asp>.

Graham, E. M.; Wada, E. 2000. Domestic reform, trade and investment liberalization, financial crisis, and foreign direct investment into Mexico, The World Economy 23(6): 777-797. doi:10.1111/1467-9701.00303

Härdle, W.; Mammen, E.; Müller, M. 1998. Testing parametric versus semiparametric modeling in generalized linear models, Journal of the American Statistical Association 93(444): 1461-1474. doi:10.2307/2670060

Härdle, W.; Müller, M.; Sperlich, S.; Werwatz, A. 2004. Nonparametric and Semiparametric Models. Springer Series in Statistics, Springer-Verlag.

Herman, M.; Chisholm, D.; Leavell, H. 2004. FDI and the effects on Society, Proceedings of the Academy for Studies in International Business 4(1): 15-18.

Hui, T.; Shang-Jin, W. 2009. The composition matters: Capital inflows and liquidity crunch during a global economic crisis International Monetary Fund, IMF Working Papers, No. 09/164.

Hutchison, M. M.; Noy, I. 2005. How bad are twins? Output costs of currency and banking crises, Journal of Money, Credit, and Banking 37(4): 725-752. doi:10.1353/mcb.2005.0043

Hyo-sik, L. 2008, December 12. Inbound FDI falls $2.6 \%$ on financial crisis. The Korea Times [online] [20 February 2009]. Available from Internet: <http://www.koreatimes.co.kr/www/news/ nation/2008/10/123_32086.html>.

Hyun, H.-J. 2006. Quality of institutions and foreign direct investment in developing countries: causality tests for cross-country panels, Journal of Business Economics and Management 7(3): $103-110$.

Kaminsky, G. L.; Reinhart, C. M. 1998. Financial crises in Asia and Latin America: Then and now, American Economic Review 88(2): 444-448.

Kian Wie, T. 2006. Policies for private sector development in Indonesia ADB Institute Discussion Paper [online] No. 46 [21 June 2008]. Available from Internet: <http://www.adbi.org/ files/2006.03.d46.private.sector.dev.ind.pdf $>$.

Kosekahyaoglu, L. 2006. A comparative analysis of FDI in Turkey and the CEECs: Is there any link between FDI and trade? Journal of Business Economics and Management 7(4): 183-200.

Loungani, P.; Razin, A. 2001. How beneficial is foreign direct investment for developing countries? Finance and Development 38(2): 6-9.

McCullagh, P.; Nelder, J.A. 1989. Generalized linear models. $2^{\text {nd }}$ ed. London: Chapman and Hall.

Müller, M. 2000. Semiparametric Extensions to Generalized Linear Models. Habilitationsschrift [online] [07 April 2008]. Available from Internet: <http://www.marlenemueller.de/publications. html>.

Müller, M. 2001. Estimation and testing in generalized partial linear models - a comparative study, Statistics and Computing 11(4): 299-309. doi:10.1023/A:1011981314532 
Nunnenkamp, P. 2006. Foreign direct investment in developing countries: What policymakers should not do and what economists don't know, Kiel Discussion Papers [online] No. 380, Institut Fur Weltwirtschaft Kiel [09 May 2007]. Available from Internet: < http://opus.zbw-kiel.de/ volltexte/2006/3849/pdf/kd380.pdf>.

Ozlale, U.; Metin-Ozcan, K. 2007. An alternative method to measure the likehood of a financial crisis in an emerging market, Physica A: Statistical Mechanics and its Applications 381: 329-337.

Pazienza, P.; Vecchione, V. 2009. Preliminary investigation of the determinants of FDI distribution in Italy, Journal of Business Economics and Management 10(2): 99-107. doi:10.3846/1611-1699.2009.10.99-107

Robinson, P. M. 1988. Root n-consistent semiparametric regression, Econometrica 56: 931-954. doi: $10.2307 / 1912705$

Schimek, M. G. 2000. Estimation and inference in partially linear models with smoothing splines, Journal of Statistical Planning and Inference 91(2): 525-540. doi:10.1016/S0378-3758(00)00197-X

Severini, T. A.; Staniswalis, J. G. 1994. Quasi-likelihood estimation in semiparametric models, Journal of the American Statistical Association: Theory and Methods 89 (426): 501-511. doi:10.2307/2290852

Speckman, P. E. 1988. Regression analysis for partially linear models, Journal of the Royal Statistical Society: Series B 50: 413-436.

Thangavelu, S. M.; Yong, Y. W; Chongvilaivan, A. 2009. FDI, growth and the Asian financial crisis: the experience of selected Asian countries, World Economy 32(10): 1461-77.

doi:10.1111/j.1467-9701.2009.01202.x

Thu, V. T. 1998. Effects of the Asian financial crisis on foreign investment in Vietnam and solutions, Economic Development Review [online] 49 [05 March 2007]. Available from Internet: $<$ http://www.ueh.edu.vn/tcptkt/english/ 1998/t9-98/998T12.html>.

Tvaronavičienè, M.; Grybaitè, V. 2007. Impact of FDI on Lithuanian economy: Insight into development of main Economic Activities, Journal of Business Economics and Management 8(4): $285-290$.

UNCTAD 2008a. Transnational corporations, and the infrastructure challenge, World Investment Report 2008. New York and Geneva: United Nations.

UNCTAD 2008b. World Investment Prospects Survey: 2008-2010. New York and Geneva: United Nations.

UNCTAD [online] 2008c. Major FDI indicators: WIR [20 April 2008]. Available from Internet: $<$ http://stats.unctad.org/FDI/ReportFolders/reportFolders.aspx $>$.

Urata, S. 1999. The East Asian economic crisis and Japanese foreign direct investment in Asia, ASEM Regional Economists' Workshop, Bali, Indonesia, September 15-17, 1999: 1-33.

World Development Indicators (WDI) 2008. FDI indicators [online] [10 April 2008]. Available from Internet: <http://www. worldbank. org/data $>$. 


\title{
FINANSŲ KRIZĖS IR TIESIOGINIŲ UŽSIENIO INVESTICIJŲ RYŠIO BESIVYSTANČIOSE ŠALYSE NUSTATYMAS TAIKANT SEMIPARAMETRINI REGRESIJOS MODELI
}

\author{
M. Ucal, K. M. Özcan, M. H. Bilgin, J. Mungo
}

Santrauka

Straipsnyje keliamas klausimas - kokia kryptimi ir kokiu stiprumu tiesioginių užsienio investicijų (TUI) ịplaukas ị besivystančios šalies šeimininkès ūki veikia finansų krizè kapitalą priimančioje šalyje. Autoriu formuluojamoms hipotezèms patvirtinti ar paneigti naudojamas semiparametrès regresijos modelis. Gauti rezultatai rodo, kad TUI turi tendenciją mažèti ne tik finansų krizès metais. Būdamos inertiškos, TUI mažèja net finansų krizei besivystančioje šalyje pasibaigus.

Reikšminiai žodžiai: semiparametrès regresijos modelis, finansų krizè, tiesioginès užsienio investicijos, besivystančios šalys.

Meltem UCAL is based at the Faculty of Economics \& Administrative Sciences, Department of Economics, Kadir Has University, Istanbul, Turkey. She received her BA, MA and PhD, all in Econometrics, from Istanbul University. She has published many articles in international and domestic journals such as Journal of Social Science, Briefing Notes in Economics, The Emprical Economics Letters, and several others. Her current research interests/publications are model selection, nonparametric regression, bootstrap, cross-validation, FDI, income inequality, and housing markets.

Kivilcim Metin ÖZCAN is an Associate Professor of Economics at Bilkent University, Ankara, Turkey. She received her PhD from the University of Oxford. Her research interests are macroeconomic modeling and time series analysis of aggregated macroeconomic and financial data. Her work has appeared in Oxford Bulletin of Economics and Statistics, Journal of Business and Economic Statistics, European Journal of Operational Research, Applied Economics, Applied Financial Economics, and Empirical Economics, Physica A, Emerging Market Finance and Trade. She is a fellow of Economic Research Forum at Cairo, Egypt and a Board member of Strategic Thinking Institute at Ankara, Turkey.

Mehmet Huseyin BILGIN. Dr, Associate Professor, Head of the Department of International Finance at Kadir Has University. His scientific interests include macroeconomics, international economics, labor economics, and Turkish economy. Author of more than 20 papers in peer-reviewed scientific journals and other publications.

Julius MUNGO is an alumni's of the CRC 649 "Economic Risk" at Humboldt-Universität zu Berlin, School of Business and Economics, Berlin, Germany. His scientific interests include dynamic semiparametric factor model, VAR, cointegration and so on. 